\title{
FIRST SIGHT RECORD OF THE CACTUS WREN IN SASKATCHEWAN AND CANADA
}

GUY J. WAPPLE, Box 1045, Biggar, Saskatchewan, SOK OMO and ALAN R. SMITH, 308-537 4th Ave. N., Saskatoon, Saskatchewan. S7K 2M6

On 15 June 1982, the authors and Linda Lahey were vacationing in the West Block of the Cypress Hills in southwestern Saskatchewan. We visited the home of Bob and Dixie Black, whose ranch is located approximately $42 \mathrm{~km}$ (25 mi.) southwest of Maple Creek. While discussing the local birdife, we asked if there had been any unusual bird species in their district recently. Bob described the following ncident.

Between the hours of 1100 and 1130 n 30 May 1982, during the height of a reak blizzard which struck southern askatchewan, Bob was sitting at their itchen table when he noticed an unamiliar bird perched outside on the atio. Calling Dixie and two other stormound visitors to view the bedraggled and obviously disoriented bird, they hoted the following field marks:

size was slightly smaller than a Robin; the head was brown with a wide white eye-stripe; the back was brown with white streaks; the bill was long and down-curved; the breast was densely spotted and the tail barred, with white spots on the outer feathers.

For about 2 minutes they studied the stray from less than $2 \mathrm{~m}$ ( 6 feet) before the bird took flight and struggled off into the storm. No binoculars were necessary, as the bird was much too close for them to have been of any use. Totally baffled by the 'mystery' bird, Bob and Dixie began leafing through the Audubon Society Field Guide to North American Birds - Western Region, attempting to locate its picture. ${ }^{9}$ When they arrived at picture number 532, the Blacks were amazed to discover that the bird in question had been a Cactus Wren! Bob said the photograph was an exact replica of their bird. When questioned by the authors on 15 June, there was no doubt in the Blacks' 
minds as to the wren's identity. When shown similar species in Robbin's, et. al., they stated it was much larger and more densely spotted below than the Rock Wren; the streaked back and barred tail ruled out both Brown and Sage Thrasher. ${ }^{7}$ After the storm subsided on 31 May and on succeeding days Bob and Dixie kept a lookout for the wren, however, it was not seen again.

According to the A.O.U. Check-List of North American Birds, the Cactus Wren is a resident of southern California, southern Nevada, southwestern Utah, western and south-central Arizona, southern New Mexico, and central Texas south to southern Baja California, Michoacan and State of Mexico. ${ }^{1}$ Based on the northern-most localities given in the text, Toquerville in southwest Utah and the Sheep Range in southern Nevada, the wren was displaced at least 1370 to $1450 \mathrm{~km}$ (850 to 900 mi.) north of its desert haunts. A further search of the literature, including reports in American Birds since 1967, failed to turn up even a single extralimital record of the Cactus Wren. ${ }^{234568}$

A study of available weather maps of the continent for, 30-31 May by the junior author revealed a low pressure system situated over southern Idaho, while a corresponding high pressure mass was located over western Kansas. Our theory, which Bob Black originally proposed, is that after the storm-centre picked up the wren in the southwestern U.S., the resulting northerly flow of air carried it up to the Cypress Hills region. Since the blizzard was a fierce one winds reaching velocities of over 100 $\mathrm{km}(60+\mathrm{mi}$.) per hour and depositing nearly $2 \mathrm{~m}(5+\mathrm{ft}$.) of snow on the Hills - the wren had no alternative but to follow along until it was able to set down somewhere to seek shelter. Conditions in the remainder of southern Saskatchewan were not as severe. The damage to the province's southwest corner was especially felt on livestock herds. Many animals were buried aliv as they sought refuge in coulees; th depressions themselves were then fille in with snow. When we arrived in th Hills on 14 June, there were still sizeabl banks of snow on the northern slope and many roads remained impassable Dixie commented on the lack of sma bird-life around the yard after 31 May

Even though this is a sight record $b$ two relatively inexperienced observers the senior author is especially confider of this record, having known the Black since 1976 as careful and cautiou birders. Both are familiar with loce species in and around their ranch. As result, we feel the Cactus Wren shoul be placed on the hypothetical lists fo both Saskatchewan and Canada.

\section{AMERICAN ORNITHOLOGISTS' UNION} 1957. Check-list of North America birds. Fifth ed. Am. Ornithol. Unior Baltimore, Md. 691 pp.

${ }^{2}$ ANDERSON, A. H. and A. ANDERSON 1973. The Cactus Wren. University Arizona Press. Tucson, Ariz. 226 pp.

${ }^{3}$ BENT, A. C. 1948. Life histories of Nort American nuthatches, wrens, thrashers and their allies. Smithsonian Inst. U.S Nat. Mus. Bull. 195. (1964 Dove Edition). 475 pp.

${ }^{4}$ GODFREY, W. E. 1966. The birds Canada. Nat. Mus. Can., Bull. No. 203 Biol. Ser. No. 73. Queen's Printer, Ot tawa. $428 \mathrm{pp}$.

${ }^{5}$ PETERSON, R. T. 1941. A field guide th western birds. Second ed. Houghtor Mifflin Company. Boston, Mass. 30 pp.

${ }^{6}$ PETERSON, R. T. 1980. A field guide to the birds. Fourth ed. Houghton Mifflin Com pany. Boston, Mass. 384 pp.

ROBBINS, C., et al. 1966. Birds of North America. Golden Press, New York, N.Y 340 pp.

8 TERRES, J. K. 1980. The Audubon societ) encyclopedia of North American birds A. A. Knopf. New York, N.Y. 1109 pp

${ }^{9}$ UDVARDY, M. 1977. The Audubon societ) field guide to North American birds western region. A. A. Knopf. New York N.Y. 854 pp. 